\title{
B-type natriuretic peptides in chronic obstructive pulmonary disease: a systematic review
}

\author{
Nathaniel M. Hawkins ${ }^{1 *}$ D, Amit Khosla', Sean A. Virani', John J. V. McMurray ${ }^{2}$ and J Mark FitzGerald ${ }^{3}$
}

\begin{abstract}
Background: Patients with chronic obstructive pulmonary disease (COPD) have increased cardiovascular risk. Natriuretic peptides (NP) in other populations are useful in identifying cardiovascular disease, stratifying risk, and guiding therapy.

Methods: We performed a systematic literature review to examine NP in COPD, utilising Medline, EMBASE, and the Cochrane Library.

Results: Fifty one studies were identified. NP levels were lower in stable compared to exacerbation of COPD, and significantly increased with concomitant left ventricular systolic dysfunction or cor pulmonale. Elevation occurred in 16 to $60 \%$ of exacerbations and persisted in approximately one half of patients at discharge. Cardiovascular comorbidities were associated with increased levels. Levels consistently correlated with pulmonary artery pressure and left ventricular ejection fraction, but not pulmonary function or oxygen saturation. NP demonstrated high negative predictive values (0.80 to 0.98 ) to exclude left ventricular dysfunction in both stable and exacerbation of COPD, but relatively low positive predictive values. NP elevation predicted early adverse outcomes, but the association with long term mortality was inconsistent.
\end{abstract}

Conclusion: NP reflect diverse aspects of the cardiopulmonary continuum which limits utility when applied in isolation. Strategies integrating NP with additional variables, biomarkers and imaging require further investigation.

Keywords: Natriuretic peptides, Chronic obstructive pulmonary disease, Heart failure, Biomarkers

\section{Background}

COPD is the only major cause of mortality for which death rates continue to rise. There remains a lack of objective measures to risk-stratify patients, standardized management of comorbidities, and therapies that prolong life. One third of deaths in COPD relate to cardiovascular disease, equaling or exceeding pulmonaryrelated mortality [1-3]. Cardiovascular therapies are proven to reduce morbidity and mortality, yet are underutilized because disease is unrecognized [4]. Simple, generalizable and cost-effective strategies are therefore needed to identify cardiovascular disease (and particularly heart failure) to improve outcomes in COPD.

\footnotetext{
* Correspondence: nat.hawkins@ubc.ca

${ }^{1}$ Division of Cardiology, University of British Columbia, BC Centre for Improved Cardiovascular Health, St. Paul's Hospital, 1081 Burrard Street, Vancouver V6Z 1Y6, BC, Canada

Full list of author information is available at the end of the article
}

The U.S. Food and Drug Administration and international guidelines have highlighted the need for biomarker development in COPD [5]. However, development is challenging and translation into clinical practice has been largely unsuccessful $[6,7]$. Given the recognized cardiovascular phenotypes within COPD, [8] the use of established cardiovascular biomarkers merits exploration. The natriuretic peptides (NP) B-type natriuretic peptide (BNP) and N-terminal fragment (NT-proBNP) are powerful independent predictors of death and adverse events in HF, a broad range of cardiovascular conditions, and even in asymptomatic individuals in the community [9]. In primary care patients at high cardiovascular risk, intensive management of those with a raised BNP detected on systematic screening reduced the incidence of heart failure and left ventricular dysfunction [10]. NP may therefore 
prove useful in identifying cardiovascular disease, stratifying risk, and guiding therapy in COPD.

However, pulmonary disease itself, pulmonary hypertension, and right ventricular strain are also associated with NP elevation. This may undermine the utility of NP in COPD across the spectrum of potential applications: reduced diagnostic accuracy for HF; impaired risk stratification due to transient changes or weak association with predictors of prognosis; and by correlation with factors unresponsive to treatment. We therefore undertook a systematic review to direct future research and provide healthcare providers with a concise, critical, unbiased synthesis of the expanding body of literature. The study aims were to define the prevalence, distribution, associations, prognostic implications, and diagnostic accuracy of peptide elevation in COPD.

\section{Methods}

\section{Participants, outcomes and study designs}

Preferred Reporting Items for Systematic reviews and Meta-Analyses (PRISMA) guidelines were followed. The population of interest was patients with COPD receiving natriuretic peptide testing. The outcome of interest was NP, including: levels and proportion elevated in different COPD populations, stratified by COPD severity (stable disease, acute exacerbation (AECOPD), associated cor pulmonale); thresholds used to define abnormal; correlations between NP and measures of ventricular and pulmonary function; risk associated with NP; and accuracy of NP in diagnosing HF. All study designs including cohort, case-control and cross-sectional were accepted.

\section{Search strategy and data collection}

MEDLINE (from 1990), EMBASE (from 1990), and the Cochrane Library were searched to June 2015, limited to adult humans, without date or language restriction. Search terms were selected by consensus and iterative database queries. Medical Subject Headings (MeSH) and Emtree terms were identified from keyword mapping and published literature. COPD was identified using $\mathrm{MeSH}$ (pulmonary disease, chronic obstructive; bronchitis, chronic), Emtree (chronic obstructive lung disease; chronic bronchitis), and keywords. NP were identified using MeSH (natriuretic peptides), Emtree (brain natriuretic peptide), and keywords. Terms and keywords were combined according to the requirements of the database. The search strategy is outlined in Appendix 1. No review protocol was registered or published. The search identified 440 articles in Medline and EMBASE, totalling 276 records after duplicate removal (Fig. 1). Case reports, reviews and conference abstracts were excluded. Two reviewers (NH and AK) screened titles and abstracts (binary yes/no) with reconciliation through discussion. Studies fulfilling the participant,

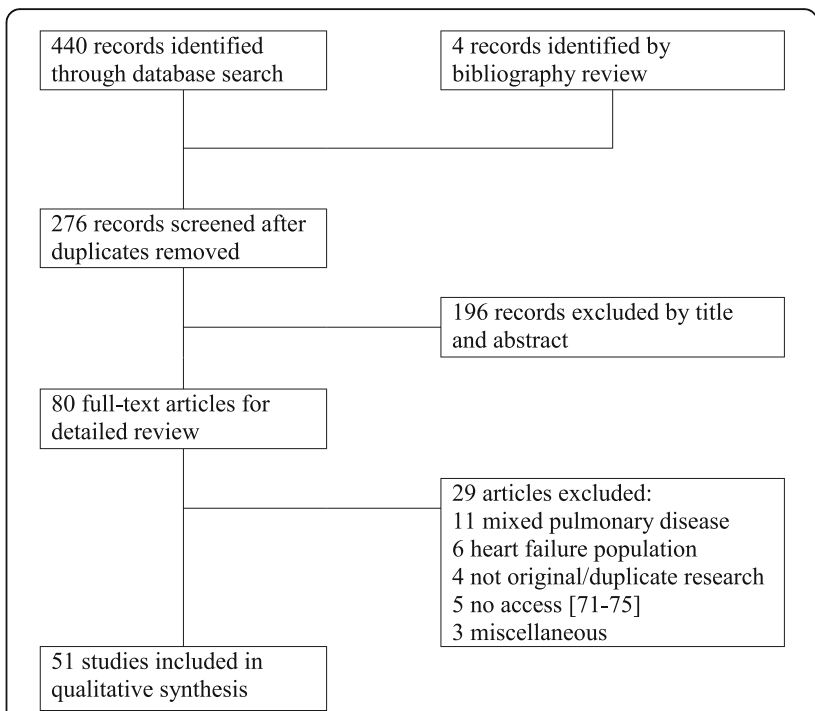

Fig. 1 Flow diagram of study selection

outcomes and study design criteria were included. Studies involving patients with different pulmonary diseases (as opposed to COPD) or only HF were excluded (Fig. 1). Variables of interest were decided a priori and expanded iteratively after pilot. Excel spreadsheets were employed as data extraction forms and populated directly by both reviewers $(\mathrm{NH}$ and AK). The following information was extracted: bibliographic details, sample size and number of centers, population, baseline characteristics and comorbidities, pulmonary function, NP outcomes.

\section{Study quality}

In accordance with the Cochrane Collaboration and Institute of Medicine guidance, risk of bias in observational studies was assessed in selected components with empirical evidence and strong clinical or theoretical grounds. A quality scale was not utilized as many have limited development methodology, validation, arbitrary weightings and inconsistent relationships with effect sizes. 7 bias domains were selected (selection, misclassification, performance, detection, reporting, information and confounding), based on the Cochrane Collaboration Risk of Bias Tool and Handbook and Agency for Healthcare Research and Quality RTI Item Banks,[11-13] Judgement of low, high or unclear risk of bias was assigned for each domain (Appendices 2, 3 and 4).

\section{Synthesis and analysis}

The evidence is presented as a narrative synthesis given the heterogeneous populations, diverse objectives and outcomes examined, varying assays and thresholds, and poorly defined confounding factors. Most importantly, 
the summary measures presented in many studies (median and ranges) require transformation for metaanalysis. We explored multiple transformation methods, [14-16] all of which declined in accuracy with increasing skew and underestimated the variance by up to half. We identified 4 main groups (stable COPD/BNP, stable COPD/NT-proBNP, exacerbation COPD/BNP, exacerbation COPD/NT-proBNP). Median/IQR was more often reported in the exacerbation and NT-proBNP studies due to skewed distributions (Table 1). Thus transformation for meta-analysis would introduce major error into already large variances in a systematic manner.

\section{Results}

Fifty one studies were identified, of which 31 were published within the preceding 5 years and 46 within the last decade.

\section{Study quality}

Risk of bias in many domains was low with respect to measurement of NP. Studies were typically small, prospective, without interventions or exposures, cohort or cross-sectional in design, and measured NP in all patients using commercial validated assays. However, approximately $50 \%$ of studies exhibited selection bias, $20 \%$ lacked objective definition of COPD, and $40 \%$ failed to report sufficient information to facilitate interpretation of NP levels (e.g. presence of HF) (Appendices 3 and 4).

\section{Natriuretic peptides levels in patients with COPD Stable COPD}

BNP and NT-proBNP levels were normal or only mildly elevated in stable ambulatory patients in whom HF was excluded or infrequent (Table 1). In the seven studies with controls, NP levels were mildly elevated (albeit significantly) in two studies and similar to controls in the remainder [17-23]. The three largest prospective cohort studies in stable COPD included a higher proportion of patients with left ventricular systolic dysfunction (LVSD) (prevalence 11 to 15\%) [24-26]. In these patients, NP were elevated approximately 5 fold compared to those without LVSD. Natriuretic peptides were also significantly elevated in patients with cor pulmonale according to various definitions [27-29].

Eight studies examined NP in stable patients stratified by severity of COPD according to the Global Initiative for Chronic Obstructive Lung Disease (GOLD) (Appendix 5). The 5 largest studies observed no significant difference in median or mean levels with severity, while the 3 smallest studies reported significantly higher NP levels in patients with more severe COPD. A single study in 170 patients reported the proportion of patients with elevated BNP stratified by COPD severity [30]. NT-proBNP was elevated in GOLD stages I to IV in 21, 21, 23 and $28 \%$ of patients, respectively $(p=0.87)$.

\section{Acute exacerbation COPD}

Average natriuretic peptide levels were modestly higher during exacerbations than in stable patients in three types of comparison (Table 1): relative to reported values from other studies in stable COPD, compared to stable controls recruited in the same study, [31, 32] and compared to repeated estimates in the same patient outside of an exacerbation episode [33-39]. The time course of biomarker release relative to exacerbation was rarely investigated. In 127 consecutive hospitalizations, NT-proBNP was elevated in $60 \%$ of patients at admission and persisted in $28 \%$ at discharge [34]. The largest study with multiple time points found no significant decline in average NTproBNP sampled on days 3, 7, 14 and 35 after the occurrence of exacerbation [38]. Of interest, significant elevation in NT-proBNP in that study were limited to patients with a history of ischaemic heart disease.

\section{Subgroups with comorbidities}

In subgroups of patients with comorbidities associated with NP release, levels were significantly increased compared to those without comorbidities. These included ischaemic heart disease, [38, 40] pulmonary emboli, [41] arrhythmia, [32] aortic stenosis, [25] pulmonary hypertension, [42] renal impairment [32, 43]. However, these comorbidities were rarely reported or searched for systematically. For example, atrial fibrillation was only reported in 7 studies.

\section{Correlates and predictors of elevated natriuretic peptides in COPD}

The most consistent association was between NP and pulmonary artery pressure, with correlation coefficients ranging from 0.28 to 0.68 , typically being around 0.5 (Table 2). In most studies with echocardiography, NP elevation was associated with left ventricular ejection fraction (LVEF) among patients with stable and exacerbation of COPD, [25, 26, 32, 35, 37, 39] even in the absence of raised pulmonary artery pressures. Right ventricular function was rarely characterized, and then using a variety of measures including ejection fraction,[19] tricuspid annular plane systolic excursion (TAPSE), [37] right ventricular diameter and hypokinesia [29, 31]. Heterogeneity and small sample sizes limits interpretation.

The relationship between NP and $F E V_{1}$ or $\mathrm{PaO}_{2}$ was inconsistent. Similar to the evidence stratifying by COPD severity, the smaller studies observed significant correlations between NP and both $\mathrm{FEV}_{1}$ or $\mathrm{PaO}_{2}$. However, correlation coefficients in the two largest studies of 


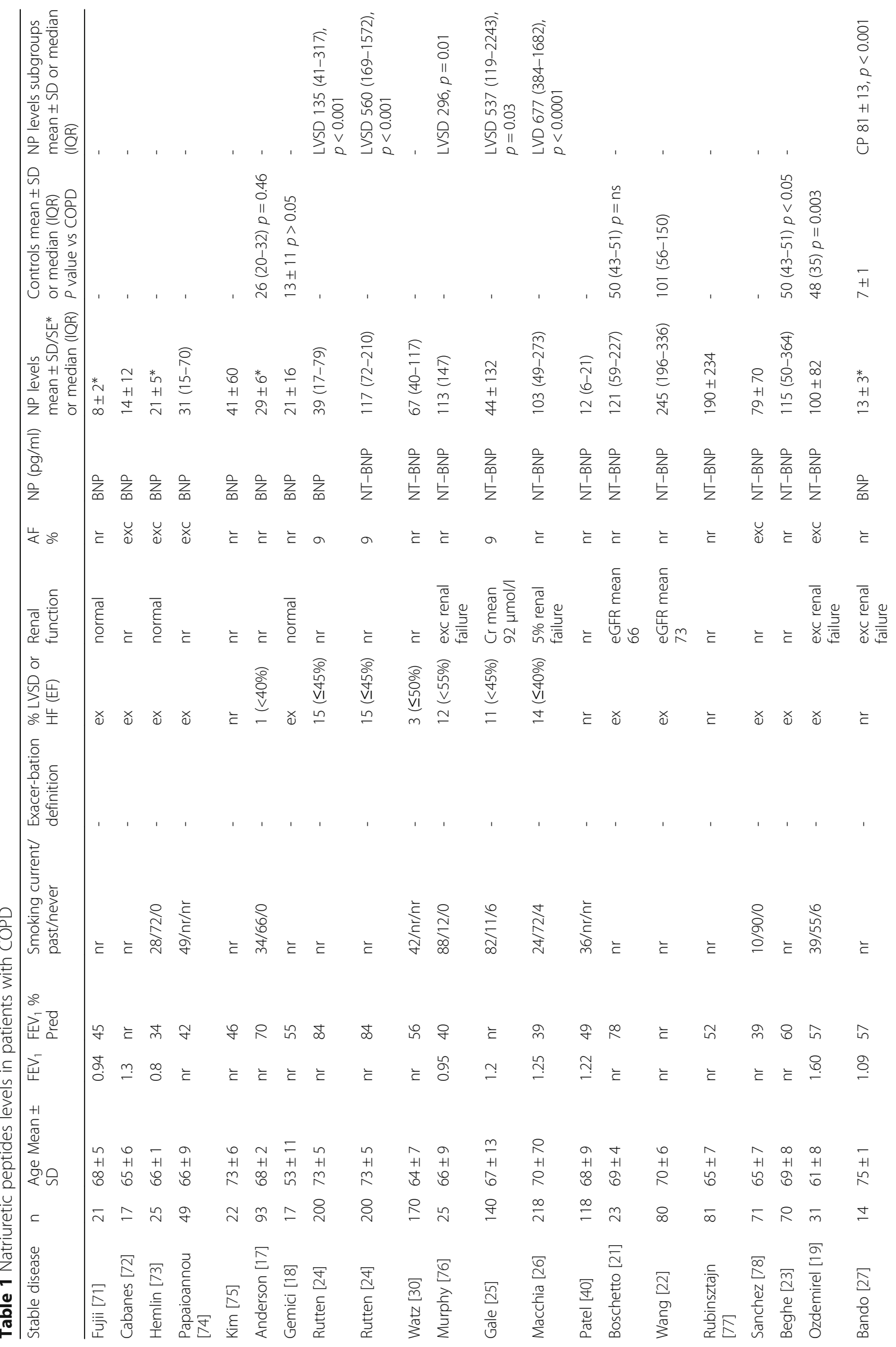




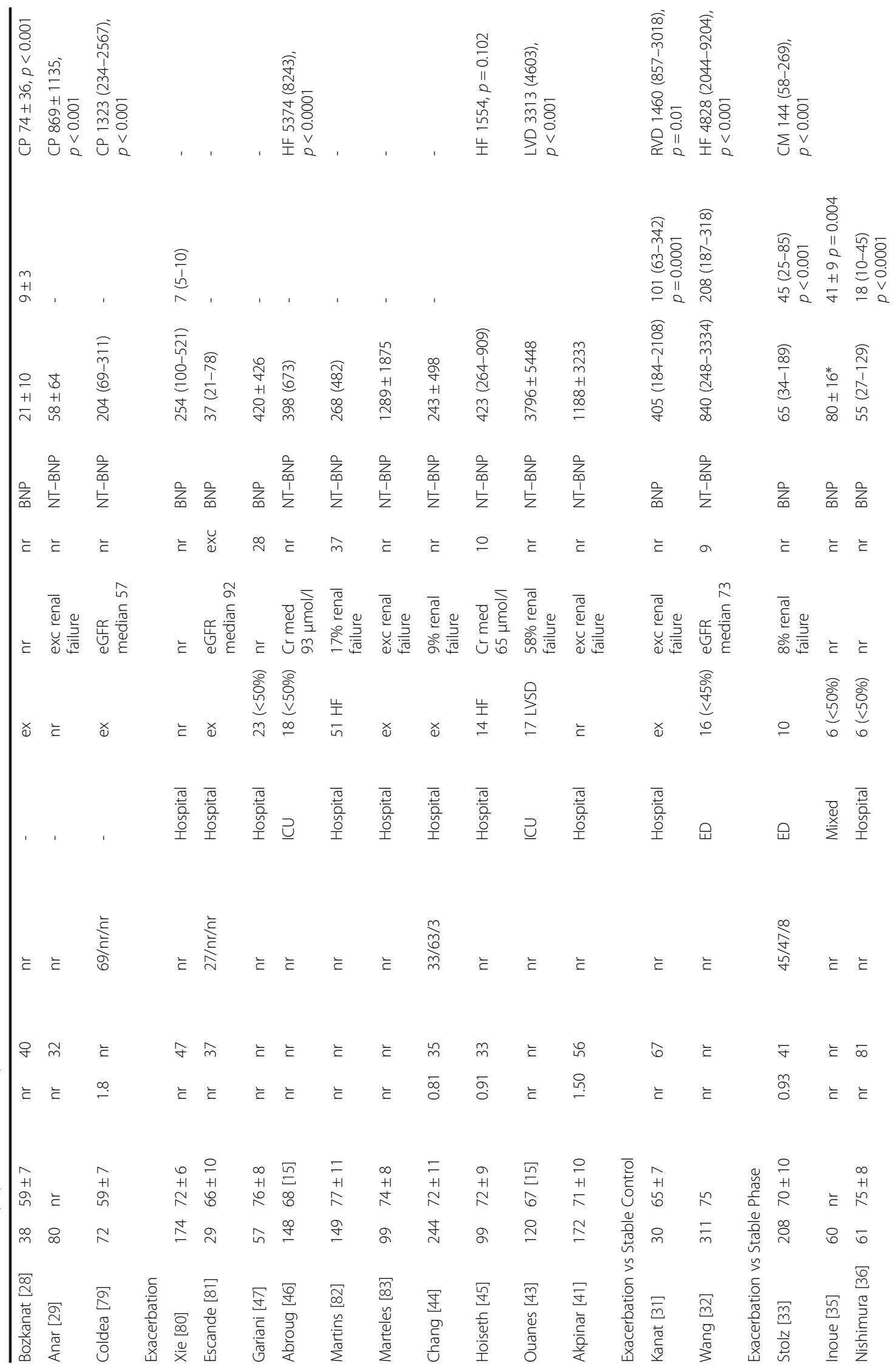


Hawkins et al. BMC Pulmonary Medicine (2017) 17:11

Page 6 of 17

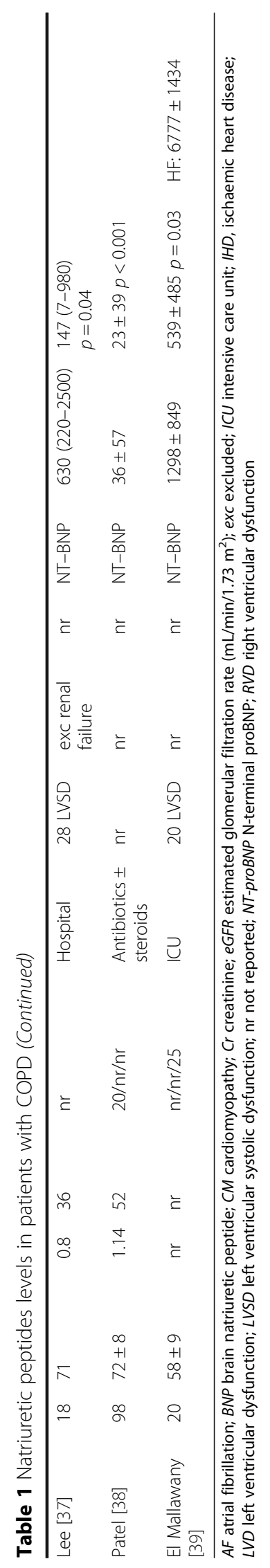




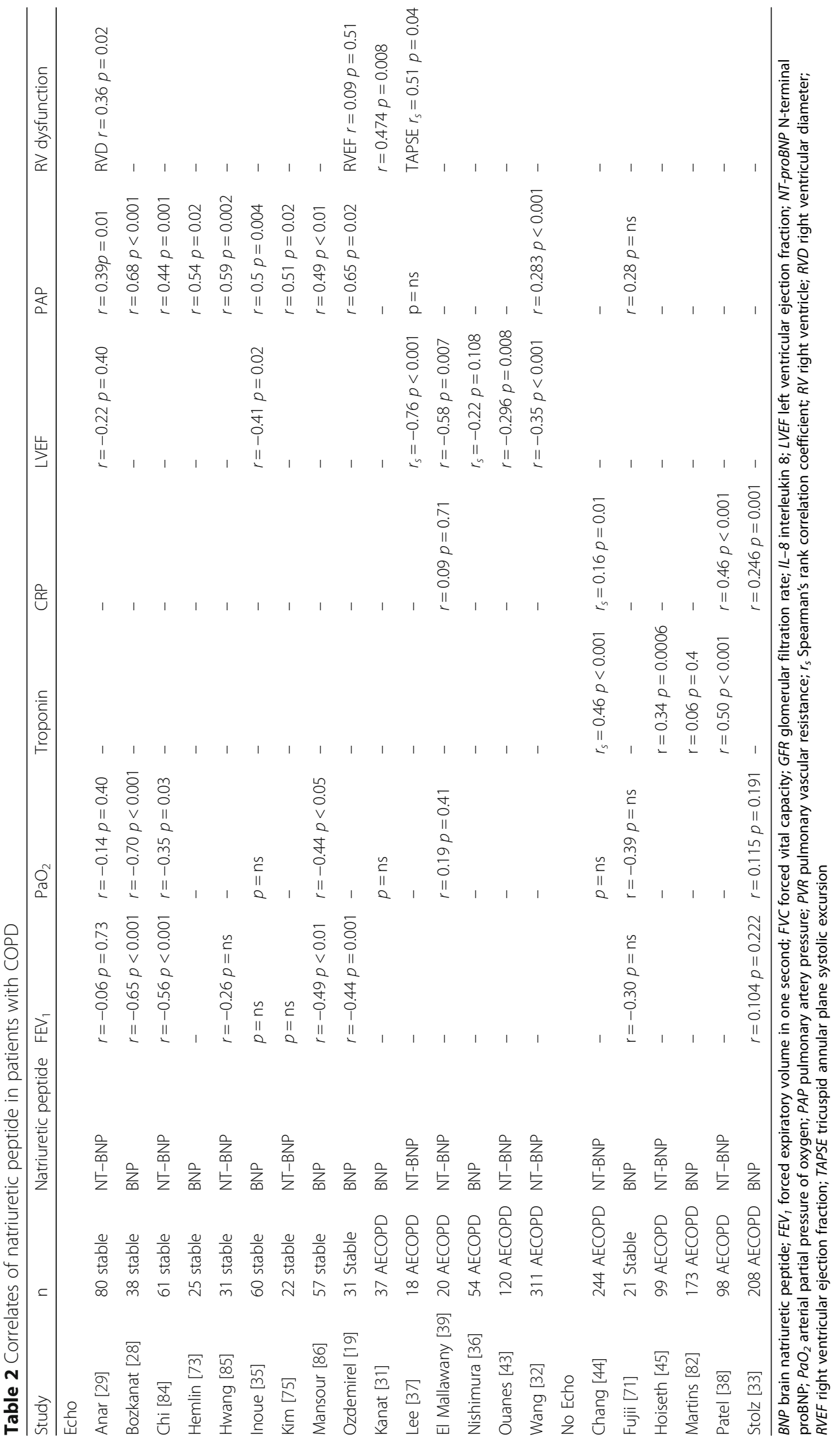


208 and 80 patients were not significant (respectively FEV $r=0.104$ and $\mathrm{PaO}_{2}$ 0.115; $\mathrm{FEV}_{1} r=0.06$ and $\mathrm{PaO}_{2}$ 0.14). A modest significant association was observed between NP and troponin in three studies $(r=0.34$ to 0.50$)$ $[38,44,45]$.

\section{Prevalence of natriuretic peptide elevation and thresholds} employed to define abnormal

Different strategies have been employed to define 'abnormal' (Table 3): ROC curve analysis to balance accuracy in predicting specific outcomes; measuring central tendency and dispersion of normal controls (e.g. mean $\pm 2 \mathrm{SD}$ ); manufacturer recommendation; existing publications or investigator selection. The proportion of patients with elevated NP according to these heterogeneous thresholds ranged from 15 to $71 \%$ in stable patients, and $16 \%$ to $60 \%$ during exacerbation. Five studies employed receiver operating curve analysis to determine optimal thresholds for detecting left ventricular dysfunction [24, 32, 39, 43, 46]. However, only one of these studies actually reported the prevalence of an elevated level according to these thresholds (approximately $50 \%$ in stable patients) [24]. Moreover, identical thresholds in different studies yielded very different frequencies of elevation. NT-proBNP $>125 \mathrm{pg} / \mathrm{ml}$ occurred in $23 \%$ and $51 \%$ of stable patients in two studies [24, 30]. Likewise, NT-proBNP $>125 \mathrm{pg} / \mathrm{ml}$ occurred in $16 \%, 27 \%$ and $44 \%$ of AECOPD in three studies [37, 38, 44].

\section{Accuracy of natriuretic peptides in detecting heart failure in patients with COPD}

Natriuretic peptides were always significantly elevated in patients with COPD and concurrent HF or LVSD compared to those without (Table 1). However, very few studies examined predictive accuracy to identify HF or LVSD, with just a single study in patients with stable COPD (Table 4) [24]. Four natriuretic peptide assays produced comparable results in 200 stable elderly patients with a clinical diagnosis of COPD. Each test excluded HF with reasonable accuracy (all negative predictive values above 0.85 , with positive predictive values approximately 0.4 ). In

Table 3 Thresholds used to define abnormal in patients with COPD

\begin{tabular}{|c|c|c|c|c|}
\hline & Natriuretic peptide & Threshold (pg/ml) & Method of selecting threshold & Proportion elevated (\%) \\
\hline \multicolumn{5}{|l|}{ Stable } \\
\hline Inoue [35] & BNP & 34 & 2 SD from mean of normal control & 37 \\
\hline Bozkanat [28] & BNP & 36 & investigator selection & $\mathrm{nr}$ \\
\hline Rutten [24] & BNP NT-BNP & 35125 & ROC curve & 4951 \\
\hline Watz [30] & NT-BNP & 125 & manufacturer reference range & 23 \\
\hline van Gestel [49] & NT-BNP & 500 & cited review article (Jelic 2006) [87] & 17 \\
\hline Macchia [26] & NT-BNP & 160 & median & $\mathrm{nr}$ \\
\hline Andersen [42] & NT-BNP & 95 & ROC for echo pulmonary hypertension & 71 \\
\hline Anar [29] & NT-BNP & 125/450 (age specific) & manufacturer reference range & 15 \\
\hline Rubinsztajn [77] & NT-BNP & 125 & manufacturer reference range & 44 \\
\hline Ozdemirel [19] & NT-BNP & 84/155 (gender specific) & $\mathrm{nr}$ & $\mathrm{nr}$ \\
\hline \multicolumn{5}{|l|}{ Exacerbation } \\
\hline Lee [51] & BNP & 88 & ROC for survival & 39 \\
\hline Gariani [47] & BNP & 500 & guidelines & 30 \\
\hline Abroug [46] & NT-BNP & 1000 and 2500 & ROC rule out and in LV dysfunction & $\mathrm{nr}$ \\
\hline Sanchez-Marteles [88] & NT-BNP & 500 & ROC for survival & 53 \\
\hline Chang [44] & NT-BNP & $220 \mathrm{pmol} / \mathrm{l}$ & local laboratory (also Lee 13) [37] & 27 \\
\hline Hoiseth [45] & NT-BNP & 2500 & based on Abroug [46] & 18 \\
\hline Marcun [34] & NT-BNP & - & age/sex adjusted 95 percentile & 60 \\
\hline Ouanes [43] & NT-BNP & 1000/2000 (renal specific) & ROC for LV dysfunction & $\mathrm{nr}$ \\
\hline Lee [37] & NT-BNP & $220 \mathrm{pmol} / \mathrm{l}$ & local laboratory (also Chang 11) [44] & 44 \\
\hline Wang [32] & NT-BNP & 935 & ROC for LV dysfunction & $\mathrm{nr}$ \\
\hline Patel [38] & NT-BNP & $220 \mathrm{pmol} / \mathrm{l}$ & based on Chang [44] & 16 \\
\hline El Mallawany [39] & NT-BNP & 900 & ROC for LV dysfunction & $\mathrm{nr}$ \\
\hline
\end{tabular}


Table 4 Accuracy of natriuretic peptides in predicting left ventricular systolic dysfunction

\begin{tabular}{llllllll}
\hline & $n$ & Population & \%LVSD (LVEF) & Threshold & Left ventricular dysfunction & NPV & PPV \\
\hline Rutten [24] & 200 & primary care elderly & $15(\leq 45 \%)$ & $\begin{array}{l}\text { BNP } 35 \mathrm{pg} / \mathrm{ml} \mathrm{NT} \text {-BNP } \\
125 \mathrm{pg} / \mathrm{ml}\end{array}$ & $\begin{array}{l}\text { panel adjudicated systolic } \\
\text { dysfunction }\end{array}$ & $\sim 0.95$ & $\sim 0.4$ \\
Abroug [46] & 148 & intensive care unit & $18(<50 \%)$ & NT-BNP $1000 \mathrm{pg} / \mathrm{ml}$ & $\begin{array}{l}\text { panel adjudicated systolic or } \\
\text { diastolic dysfunction }\end{array}$ & 0.94 & 0.78 \\
Gariani [47] & 57 & hospitalization retrospective & $23(<50 \%)$ & BNP $500 \mathrm{pg} / \mathrm{ml}$ & $\begin{array}{l}\text { systolic dysfunction diastolic } \\
\text { dysfunction }\end{array}$ & 0.880 .80 & 0.470 .41 \\
Wang [32] & 311 & hospitalization & $16(<45 \%)$ & NT-BNP $935 \mathrm{pg} / \mathrm{ml}$ & $\begin{array}{l}\text { panel adjudicated systolic or } \\
\text { diastolic dysfunction }\end{array}$ & 0.98 & 0.47 \\
\hline
\end{tabular}

BNP B-type natriuretic peptide; LVEF left ventricular ejection fraction; LVSD left ventricular systolic dysfunction; NPV negative predictive value; NT-proBNP N-terminal proBNP; PPV positive predictive value

three studies of patients with AECOPD, NP demonstrated high negative predictive values $(0.80$ to 0.98$)$ to exclude left ventricular dysfunction applying thresholds exceeding the manufacturers' guidance (Table 4) [32, 46, 47]. However, as in the stable population the positive predictive values were relatively low. Two studies also assessed ability to detect systolic and diastolic dysfunction separately [24, 47]. The receiver operating characteristic areas and overall accuracy in the latter were lower though remained acceptable.

\section{Prognostic significance of natriuretic peptides in COPD}

We identified 12 studies (6 stable and 6 exacerbation of COPD) reporting the association between NP and prognosis, in which the prognostic significance of elevation was inconsistent (Table 5). Among stable patients, the association between NP and survival over 1 to 4 years failed to remain significant after multivariable adjustment in 3 studies [25, 35, 48]. However, NT-proBNP $>500 \mathrm{pg} / \mathrm{ml}$ predicted one year mortality in 144 patients with predominantly mild to moderate COPD and

Table 5 Prognostic significance of natriuretic peptides in COPD

\begin{tabular}{|c|c|c|c|c|c|c|c|c|}
\hline & $\mathrm{n}$ & Follow up & $\begin{array}{l}\text { Echo } \\
(\%)\end{array}$ & $\begin{array}{l}\text { Heart failure } \\
\text { details }\end{array}$ & $\begin{array}{l}\text { Natriuretic peptide } \\
\text { threshold }\end{array}$ & Endpoints & Unadjusted risk & Adjusted risk \\
\hline \multicolumn{9}{|l|}{ Stable } \\
\hline Inoue [35] & 60 & 3 years & 53 & $6 \%<50 \%$ & $\mathrm{BNP}>34.2$ & $\begin{array}{l}\text { death } \\
\text { exacerbation }\end{array}$ & not significant increased & $\begin{array}{l}\text { not significant HR } 3.8 \\
(1.2-12.7) p=0.02\end{array}$ \\
\hline Gale [25] & 140 & 1 year & 100 & $11 \% \mathrm{EF}<45 \%$ & $\begin{array}{l}\text { highest vs lowest } \\
\text { quartile }\end{array}$ & $\begin{array}{l}\text { death } \\
\text { hospitalization }\end{array}$ & RR $3.0(p=0.001)$ & $\begin{array}{l}\text { not significant not } \\
\text { significant }\end{array}$ \\
\hline $\begin{array}{l}\text { Waschki } \\
{[48]}\end{array}$ & 170 & 48 months & 100 & - & - & death & HR 1.47 (1.05-2.06) & $1.16(0.97-1.39)$ \\
\hline $\begin{array}{l}\text { Andersen } \\
{[42]}\end{array}$ & 117 & 2.8 years & 100 & - & NT-proBNP <95 ng/L & death & HR $0.29(0.09-0.97) p=0.04$ & - \\
\hline $\begin{array}{l}\text { van Gestel } \\
{[49]}\end{array}$ & 144 & 1 year & 100 & ex $E F \leq 40 \%$ & $\begin{array}{l}\text { NT-proBNP } \\
>500 \mathrm{pg} / \mathrm{ml}\end{array}$ & death & HR 4.5 (1.5-13.5) & HR 7.7 (1.6-37.4) \\
\hline Zeng [50] & 220 & 22 months & - & $26 \% \mathrm{HF}$ & - & death & - & $1.61(1.27-2.06)$ \\
\hline \multicolumn{9}{|c|}{ Exacerbation } \\
\hline Stolz [33] & 208 & 2 year & 75 & $10 \%$ LVSD & per $100 \mathrm{pg} / \mathrm{ml}$ & $\begin{array}{l}\text { death ICU } \\
\text { admission }\end{array}$ & $\begin{array}{l}\text { not significant } 1.12(1.03- \\
1.22)\end{array}$ & $\begin{array}{l}\text { not significant } \\
1.13(1.0-1.24)\end{array}$ \\
\hline Lee [51] & 67 & inpatient & - & - & $\mathrm{BNP}>88 \mathrm{pg} / \mathrm{ml}$ & death & - & OR 21.2 (2.5-180.4) \\
\hline $\begin{array}{l}\text { Chang } \\
\text { [44] }\end{array}$ & 244 & 1 year & 0 & $\begin{array}{l}\text { acute cardiac } \\
\text { disease ex }\end{array}$ & $\begin{array}{l}\text { NT-proBNP }>220 \\
\mathrm{pmol} / \mathrm{L}\end{array}$ & $\begin{array}{l}\text { death } 30 \text { day } \\
\text { death } 1 \text { year }\end{array}$ & $\begin{array}{l}\text { OR } 9.0(3.1-26.2) p<0.001 \\
1 \text { year not significant }\end{array}$ & $\begin{array}{l}\text { OR } 7.5(1.9-28.9) p=0.004 \\
1 \text { year not significant }\end{array}$ \\
\hline $\begin{array}{l}\text { Marcun } \\
{[34]}\end{array}$ & 127 & 6 month & 100 & $\begin{array}{l}13 \% \mathrm{EF}<55 \% \\
42 \% \mathrm{DD}\end{array}$ & $\begin{array}{l}\text { age/gender } \\
\text { adjusted }\end{array}$ & $\begin{array}{l}\text { death } \\
\text { hospitalization }\end{array}$ & $\begin{array}{l}\text { HR } 5.49 \text { (1.25-24.00) } \\
\text { HR } 1.34 \text { (0.84-2.63) }\end{array}$ & $\begin{array}{l}\text { HR } 4.20 \text { (1.07-14.01) } \\
\text { HR 1.48 (0.60-3.69) }\end{array}$ \\
\hline $\begin{array}{l}\text { Medina } \\
\text { [52] }\end{array}$ & 192 & 1 year & 0 & exclude prior & $\begin{array}{l}\text { NT-proBNP } \\
>588 \mathrm{pg} / \mathrm{ml}\end{array}$ & death & $\begin{array}{l}\text { OR } 3.90(1.46-10.47) \\
p=0.006\end{array}$ & $\begin{array}{l}\text { OR } 3.30(1.11-9.85) \\
p=0.034\end{array}$ \\
\hline $\begin{array}{l}\text { Hoiseth } \\
\text { [45] }\end{array}$ & 99 & $\begin{array}{l}\text { median } \\
1.9 \text { years }\end{array}$ & 0 & $\begin{array}{l}21 \% \text { vs } 9 \% \\
\text { tertile } 3 \text { vs } 1\end{array}$ & tertile 3 vs 1 & death & $\begin{array}{l}\text { HR } 6.9(3.0-16.0) \\
p<0.0001\end{array}$ & $\operatorname{HR} 3.2(1.3-8.1) p=0.012$ \\
\hline
\end{tabular}

$B N P$ B-type natriuretic peptide; COPD chronic obstructive pulmonary disease; $D D$ diastolic dysfunction; $E F$ left ventricular ejection fraction; $H F$ heart failure; $H R$ hazard ratio; LVSD left ventricular systolic dysfunction; NT-proBNP N-terminal pro BNP; OR odds ratio; RR relative risk 
preserved LVEF (>40\%) undergoing major vascular surgery (adjusted HR 7.7 [95\% 1.6-37.4]) [49]. NT-proBNP was also associated with all-cause mortality in a larger cohort of 220 elderly men with COPD (adjusted HR 1.61 [1.27-2.06]), although $26 \%$ of that cohort had documented HF [50].

In patients with AECOPD, NP independently predicted short term outcomes including intensive care unit admission, [33] inpatient and 30 day mortality [44, 51]. Median BNP was also significantly higher in failed (inpatient death or early re-hospitalisation) compared to successful discharges following AECOPD hospitalization (median (IQR) 261 (59-555) vs 49 (24-104) pg/ml) [36]. The relationship with longer term survival was less certain. Natriuretic peptides failed to predict mortality at 1 and 2 years in 244 and 208 consecutive patients hospitalized or presenting to the emergency department with exacerbation [33, 44]. However, elevated NP were independently associated with increased mortality at 6 months, 1 year and nearly 2 years in three subsequent studies (respectively HR 4.2, OR 3.3 and HR 3.2) $[34,45,52]$.

\section{Discussion}

\section{Causes of natriuretic peptide elevation in patients with} and without COPD

Myocardial stretch in either ventricle consequent to volume or pressure overload increases NP levels [53]. Causes include heart failure with reduced and preserved ejection, [54, 55] right ventricular failure, [56] pulmonary emboli, $[41,57]$ acute coronary syndromes, [58, 59] valvular heart disease, [60] and arrhythmias [61]. Advancing age and renal dysfunction are also associated with elevated NT-proBNP concentrations [62]. Many of these factors are present in stable COPD and common non-infective precipitants of exacerbation [32, 41, 63]. The presence and extent of each factor varies significantly from patient to patient, and is largely independent of COPD severity or acute right ventricular dysfunction. Thus NP levels are higher during acute exacerbation or chronic decompensation (cor pulmonale) than stable disease, and exhibit significant variability with skewed distributions.

By systematically searching and aggregating individual studies, our review highlights several new and consistent observations which suggest NP release is multifactorial with limited direct relationship to COPD. First, NP levels are increased even in some patients with mild COPD without arterial hypoxaemia, severe pulmonary hypertension or right ventricular dysfunction. Second, levels are stable or exhibit only a minor gradient with increasing COPD severity. Third, the magnitude of the correlation coefficients ( $r$ ) suggests only approximately $25 \%$ to $50 \%$ of the variance $\left(r^{2}\right)$ in NP is attributable to any single variable. Moreover, correlation between left and right ventricular function is likewise modest (LVEF and TAPSE $r=0.46$ in one study), [37] indicating only around $20 \%$ of the variance in function of either ventricle is explained by the function of the other.

\section{Prognostic significance of natriuretic peptides}

Individual studies have concluded that NP may be useful in risk stratifying patients with COPD [34, 44, 49]. However, the overall literature has not previously been summarized. The association with longer term outcomes was inconsistent in both stable and exacerbation populations. Our findings highlight many of the challenges in developing biomarker strategies: relatively small sample sizes; variable performance in heterogeneous populations; and failure to replicate findings from derivation to validation cohorts [7]. At present there is insufficient evidence to recommend routine risk stratification using NP.

The more consistent prediction of early outcomes following exacerbations suggests that NP are more strongly associated with acute pathologies rather than COPD itself $[33,44,51]$. The precise causes remains unclear, as risk associated with many acute events improves with time e.g. HF, PE. Nevertheless, unrecognised LVSD undoubtedly underpins many adverse outcomes. While NP levels were typically modest, [44] up to one fifth of patients with AECOPD had marked elevation indicative of probable left heart failure (although acute right ventricular strain remains possible) [45]. Moreover, the significant unadjusted association between NT-proBNP and mortality in one study was nulled after adjustment for LVEF and valvular disease [25]. This hypothesis is further supported by the high prevalence of unrecognised heart failure in imaging and autopsy studies, [64] and the improved outcomes associated with angiotensin converting enzyme inhibitors and beta-blockers in observational COPD studies $[65,66]$.

\section{Clinical application of natriuretic peptides in COPD}

Natriuretic peptides exhibit lower diagnostic accuracy for HF in COPD than in populations with acute dyspnoea, $[67,68]$ due to greater overlap of NP distributions in the respective states to be distinguished: levels are elevated in stable and exacerbation of COPD, and lower in stable compared to acute HF. The threshold providing adequate sensitivity and negative predictive value must generate sufficiently few false positives to integrate into systems of care, be cost-effective, and improve outcomes. However, the positive predictive values in the 3 stable or exacerbation populations we identified ranged from 0.4 to 0.47 . This compares unfavourably with a recent meta-analysis of NP in the acute care 
setting, which reported positive predictive values ranging from 0.67 and 0.64 for BNP and NT-proBNP respectively at the guideline recommended lower thresholds, rising to 0.85 and 0.80 respectively for mid-range values [69]. The resulting increase in false positive results will increase demand on imaging services to confirm or refute the diagnosis.

\section{Directions for future research}

To improve generalizability and interpretation, future studies should use validated assays in consecutive patients, and standardized definitions for COPD, HF and comorbidities. Detailed cardiovascular profiles and imaging are needed to systematically define pathologies contributing to NP elevation. Levels should be reported using guideline and manufacturer recommended thresholds, for both the overall population and stratified according to presence or absence of predictors of NP elevation, particularly left ventricular dysfunction. Larger studies examining cause-specific outcomes are needed. Integrating NP with clinical variables and simple investigations such as electrocardiograms should be evaluated to reduce false positive results and develop cost-effective screening strategies. The goal of improving outcomes is particularly challenged by the inconsistent prognostic implications of NP in COPD in studies to date. The greatest incremental prognostic and therapeutic value is likely in populations with unrecognized heart failure and cardiovascular disease amenable to treatment $[34,45,70]$.

\section{Limitations}

Most of the identified studies were single centre with limited numbers of patients and endpoints. The patient populations, assays and cutoffs for NP, and definitions of LVSD and HF were heterogeneous. No study systematically defined causes of NP elevation, and the proportion amenable to therapy e.g. arrhythmia, ischaemia, LVSD, pulmonary emboli. These comorbidities will strongly influence every outcome examined, from symptoms to prognosis. The causes of death in relation to NP elevation also require clarification.

\section{Conclusions}

Natriuretic peptides are often increased in patients with COPD, reflecting three complex interwoven aspects of the cardiopulmonary continuum: left heart systolic and diastolic dysfunction; pulmonary vascular and right heart remodelling; and global cardiovascular risk and comorbidities. The additional peptide elevation during exacerbations is likely a marker of both acute strain and varying degrees of underlying cardiopulmonary disease: in some patients effectively a stress test and harbinger of future adverse events. The balance of these pathophysiologic abnormalities within populations is unclear. The goal is to untangle this heterogeneity, to identify individuals at greatest risk and facilitate targeted interventions. Strategies integrating NP with additional variables, biomarkers and imaging require further investigation.

\section{Appendix 1}

Search strategy.

Combined Medline and Embase search strategy.

Medline and Embase

1) (exp pulmonary disease, chronic obstructive/or exp bronchitis, chronic/) USE mesd

2) (exp *chronic obstructive lung disease/or *exp chronic bronchitis) USE emezd

3) ((obstruct*) adj2 (pulmonary or lung* or airway" or airflow* or bronch" or respiratory")).ti,ab.

4) (COPD or COAD or COBD).mp.

5) or/1-4

6) (exp natriuretic peptides) USE mesd

7) (exp brain natriuretic peptide) USE emezd

8) (natriuretic adj2 peptide\$ or BNP or proBNP).mp.

9) or $/ 6-8$

10) 5 and 9

11) limit 10 to humans

12) limit 11 to yr = '1990-Current'

13) 12 not exp newborn/not exp infant/not exp child/ not exp adolescent/

14) 13 not (case report" or review* or comment* or editorial* or note* or conference abstract*).pt

15)..dedup 14

\section{Appendix 2}

Description of 7 risk of bias domains assessed.

Table 6 Risk of bias domains assessed

\begin{tabular}{ll}
\hline Selection & $\begin{array}{l}\text { Is there consecutive or random participant } \\
\text { sampling? }\end{array}$ \\
\hline Misclassification & $\begin{array}{l}\text { Are key inclusion/exclusion criteria clearly stated } \\
\text { and defined by valid and reliable measures? }\end{array}$ \\
Performance & $\begin{array}{l}\text { Did the study vary from the protocol proposed by } \\
\text { the investigators, and was there appropriate ethical } \\
\text { approval? } \\
\text { Is the study design prospective, retrospective, or } \\
\text { metection }\end{array}$ \\
Reporting & $\begin{array}{l}\text { Are important primary outcomes missing from the } \\
\text { results? }\end{array}$ \\
Information & $\begin{array}{l}\text { Were valid and reliable measures used consistently } \\
\text { across all study participants to assess outcomes, } \\
\text { exposures or interventions? } \\
\text { Were important confounding and effect modifying } \\
\text { variables accounted for in the design and/or } \\
\text { Interpretation }\end{array}$ \\
\hline
\end{tabular}




\section{Appendix 3}

Risk of bias summary.

Chart demonstrating overall proportion of studies classified as low, unclear or high risk of bias within the 7 domains.

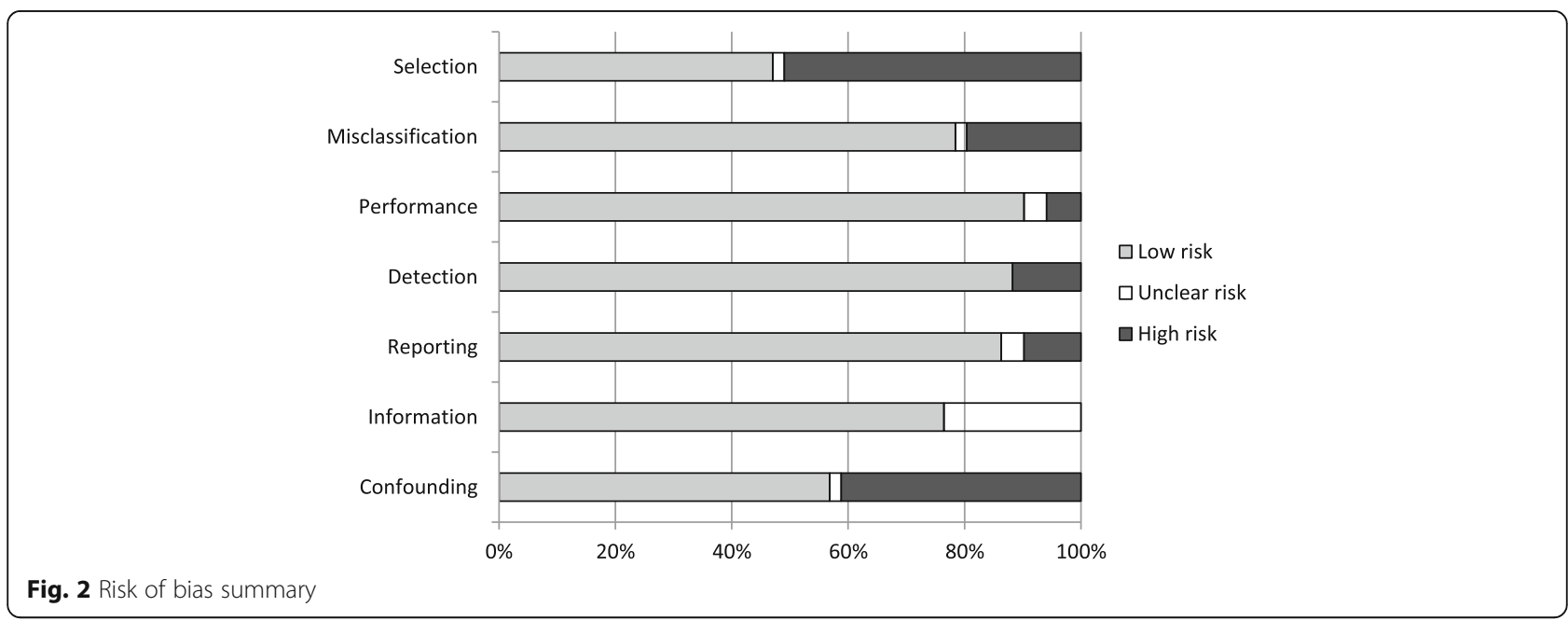




\section{Appendix 4}

Table reporting risk of bias within the 7 domains for each study.

Table 7 Risk of bias in individual studies

\begin{tabular}{|c|c|c|c|c|c|c|c|}
\hline & Selection & Misclassify & Performance & Detection & Reporting & Information & Confounding \\
\hline Abroug 06 [46] & Low & High & Low & Low & Low & Low & Low \\
\hline Agoston-Coldea 14 [79] & High & Low & Low & Low & Low & Low & Low \\
\hline Akpinar 14 [41] & Low & Low & Low & Low & Low & Low & High \\
\hline Anar 12 [29] & High & Low & High & Low & Low & Low & High \\
\hline Andersen 12 [42] & High & Low & Low & Low & High & Low & High \\
\hline Anderson 13 [17] & Low & Low & Low & Low & Low & Low & Low \\
\hline Bando 99 [27] & High & High & Low & Low & Low & Low & High \\
\hline Beghe 13 [23] & High & Low & Low & Low & Low & Unclear & High \\
\hline Boschetto 13 [21] & Low & Low & Low & Low & Low & Unclear & Low \\
\hline Bozkanat 05 [28] & High & High & Low & Low & Low & Low & Low \\
\hline Cabanes 01 [72] & Low & Low & Low & Low & Low & Low & Low \\
\hline Chang 11 [44] & Low & Low & Low & Low & Low & Low & Low \\
\hline Chi 12 [84] & High & Low & Low & Low & Low & Low & Low \\
\hline El Mallawany 14 [39] & High & High & Low & Low & Low & Low & High \\
\hline Escande 14 [81] & High & Low & Low & Low & Low & Unclear & Low \\
\hline Fujii 99 [71] & High & Low & Low & Low & Low & Low & Low \\
\hline Gale 11 [25] & Low & Low & Low & Low & Low & Low & Low \\
\hline Gariani 11 [47] & High & High & Low & High & High & Low & High \\
\hline Gemici 08 [18] & High & Low & Low & Low & Low & Low & Low \\
\hline Hemlin 07 [73] & High & Low & Low & Low & Low & Unclear & Low \\
\hline Hoiseth 12 [45] & Low & Low & Low & Low & Low & Low & Low \\
\hline Hwang 07 [85] & High & Unclear & Unclear & High & Unclear & Unclear & Unclear \\
\hline Inoue 09 [35] & High & Low & Low & Low & Low & Low & High \\
\hline Kanat 07 [31] & Low & Low & Low & Low & Low & Low & Low \\
\hline Kim 10 [75] & High & Low & Low & Low & Low & Low & High \\
\hline Lee 04 [51] & High & Low & Unclear & High & High & Unclear & High \\
\hline Lee 13 [37] & High & Low & Low & Low & Low & Low & Low \\
\hline Lopez-Sanchez 13 [78] & Low & Low & Low & Low & Low & Unclear & High \\
\hline Macchia 12 [26] & Low & Low & Low & Low & Low & Low & Low \\
\hline Marcun 12 [34] & Low & Low & Low & Low & Low & Low & High \\
\hline Martins 09 [82] & High & High & Low & High & High & Unclear & High \\
\hline Murphy 09 [76] & Low & Low & Low & Low & Low & Low & Low \\
\hline Nishimura 14 [36] & Low & Low & Low & Low & Low & Unclear & High \\
\hline Ouanes 12 [43] & Low & Low & Low & Low & Low & Low & Low \\
\hline Ozdemirel 14 [19] & Low & Low & Low & Low & Low & Low & Low \\
\hline Papaioannou 10 [74] & Low & Low & Low & Low & Low & Low & Low \\
\hline Patel 12 [40] & High & Low & Low & Low & High & Low & High \\
\hline Patel 13 [38] & High & Low & Low & Low & Low & Low & High \\
\hline Rubinsztajn 13 [77] & Low & Low & High & High & Low & Low & High \\
\hline Rutten 07 [24] & Low & High & Low & Low & Low & Low & Low \\
\hline Sanchez-Marteles 09 [83] & Low & Low & Low & Low & Low & Low & Low \\
\hline
\end{tabular}


Table 7 Risk of bias in individual studies (Continued)

\begin{tabular}{|c|c|c|c|c|c|c|c|}
\hline Sanchez-Marteles 10 [88] & Low & Low & Low & Low & Unclear & Low & High \\
\hline Stolz 08 [33] & Low & Low & Low & Low & Low & Low & High \\
\hline van Gestel 10 [49] & High & Low & Low & Low & Low & Low & Low \\
\hline Wang 11 [20] & High & Low & Low & Low & Low & Low & Low \\
\hline Wang 13 [22] & High & High & Low & Low & Low & Unclear & Low \\
\hline Wang 13 [32] & Low & High & Low & Low & Low & Low & Low \\
\hline Waschki 11 [48] & Low & Low & Low & Low & Low & Low & Low \\
\hline Watz 08 [30] & High & Low & Low & Low & Low & Unclear & Low \\
\hline Xie 13 [80] & Unclear & High & High & Low & Low & Low & High \\
\hline Zeng 13 [50] & High & Low & Low & High & Low & Unclear & High \\
\hline
\end{tabular}

\section{Appendix 5}

Table reporting natriuretic peptide levels in 8 studies stratified by COPD severity according to GOLD classification.

Table 8 Natriuretic peptide levels in patients with COPD stratified by severity

\begin{tabular}{|c|c|c|c|c|c|}
\hline & $n$ & Population & $\begin{array}{l}\text { Natriuretic } \\
\text { peptide } \\
\text { (pg/ml) }\end{array}$ & $\begin{array}{l}\text { Median or mean peptide level according to GOLD I/II/ } \\
\text { III/IV }\end{array}$ & $\begin{array}{l}\text { Significant difference across GOLD } \\
\text { groups }\end{array}$ \\
\hline Rutten [24] & 118 & stable & NT-proBNP & $\sim 127 / 119 / 136 / 169$ & $p=\mathrm{NS}$ \\
\hline Watz [30] & 170 & stable & NT-proBNP & $69 / 62 / 67 / 73$ & $p=0.78$ \\
\hline Inoue [35] & 60 & stable & BNP & $\sim 30 / 30 / 50 / 65$ & $p<0.01$ \\
\hline $\begin{array}{l}\text { van Gestel } \\
\text { [49] }\end{array}$ & 144 & stable & NT-proBNP & 212/170/352/- & \\
\hline Mansour [86] & 57 & stable & BNP & excluded/38/60/78 & $p<0.05$ \\
\hline Chi [84] & 61 & stable & NT-proBNP & excluded/112/151/250 & $p=0.02$ \\
\hline Nishimura [36] & 190 & stable & BNP & 18/26/22/17 & $p=0.53$ \\
\hline $\begin{array}{l}\text { Rubinsztajn } \\
\text { [77] }\end{array}$ & 81 & stable & NT-proBNP & $114 / 232 / 155 / 231$ & $p=\mathrm{NS}$ \\
\hline
\end{tabular}

BNP brain natriuretic peptide; GOLD, Global Initiative for Chronic Obstructive Lung Disease; NT-proBNP N-terminal proBNP

\section{Abbreviations}

AECOPD: Acute exacerbation of chronic obstructive pulmonary disease: BNP: B-type natriuretic peptide; COPD: Chronic obstructive pulmonary disease: $F V_{1}$ : Forced expiratory volume in $1 \mathrm{~s}$; GOLD: Global Initiative for Chronic Obstructive Lung Disease; HF: Heart failure; LVEF: Left ventricular ejection fraction (LVEF); LVSD: Left ventricular systolic dysfunction; MeSH: Medical Subject Headings; NP: Natriuretic peptides; NT-proBNP: $\mathrm{N}$-terminal pro B-type natriuretic peptide; TAPSE: Tricuspid annular plane systolic excursion

\section{Acknowledgements}

Our thanks to Mohsen Sadatsafavi for providing additional comments on the manuscript.

\section{Funding}

The authors received no financial support in preparation of the manuscript.

\section{Authors' contributions}

$\mathrm{NMH}$ designed the review, collected data, and drafted the manuscript; AK collected data and helped draft the manuscript; SV participated in study design, interpreted results, and critically revised the manuscript; JJVM interpreted results and revised critically for intellectual content; JMF conceived the review and revised critically for intellectual content. All authors read and approved the final manuscript and take responsibility for all aspects of the work.

\section{Availability of data and material}

The datasets during and/or analysed during the current study available from the corresponding author on reasonable request.

Competing interests

Drs Hawkins, Khosla, Virani, McMurray and FitzGerald have no competing interests to declare.

\section{Consent for publication}

Not applicable.

Ethics approval and consent to participate

Not applicable.

\section{Author details}

${ }^{1}$ Division of Cardiology, University of British Columbia, BC Centre for Improved Cardiovascular Health, St. Paul's Hospital, 1081 Burrard Street, Vancouver V6Z 1Y6, BC, Canada. ' Glasgow Cardiovascular Research Centre, University of Glasgow, Glasgow, UK. ${ }^{3}$ Division of Respiratory Medicine, University of British Columbia and Institute for Heart and Lung Health, Vancouver, Canada. 
Received: 3 August 2016 Accepted: 9 December 2016 Published online: 10 January 2017

\section{References}

1. Keistinen T, Tuuponen T, Kivela SL. Survival experience of the population needing hospital treatment for asthma or COPD at age 50-54 years. Respir Med. 1998;92:568-72.

2. Vilkman S, Keistinen T, Tuuponen T, Kivela SL. Survival and cause of death among elderly chronic obstructive pulmonary disease patients after first admission to hospital. Respiration. 1997;64:281-4.

3. McGarvey LP, John M, Anderson JA, Zvarich M, Wise RA. Ascertainment of cause-specific mortality in COPD: operations of the TORCH clinical endpoint committee. Thorax. 2007:62:411-5.

4. Hawkins NM, Petrie MC, Jhund PS, Chalmers GW, Dunn FG, McMurray JJ. Heart failure and chronic obstructive pulmonary disease: diagnostic pitfalls and epidemiology. Eur J Heart Fail. 2009;11:130-9.

5. Guidance for Industry: Chronic Obstructive Pulmonary Disease: Developing Drugs for Treatment. United States Food and Drug Administration. Center for Drug Evaluation and Research (CDER) http://www.fda.gov/downloads/drugs/ guidancecomplianceregulatoryinformation/guidances/ucm071575.pdf. 2016. Accessed 03 Dec 2016.

6. Hollander Z, DeMarco ML, Sadatsafavi M, McManus BM, Ng RT, Sin DD Biomarker Development in COPD: Moving from P-Values to Products to Impact Patient Care. Chest. 2016. http://dx.doi.org/10.1016/j.chest.2016.09. 012.

7. Sin DD, Hollander Z, DeMarco ML, McManus BM, Ng RT. Biomarker development for chronic obstructive pulmonary disease. From discovery to clinical implementation. Am J Respir Crit Care Med. 2015;192:1162-70.

8. Vanfleteren LE, Spruit MA, Groenen M, et al. Clusters of comorbidities based on validated objective measurements and systemic inflammation in patients with chronic obstructive pulmonary disease. Am J Respir Crit Care Med. 2013;187:728-35.

9. Wang TJ, Larson MG, Levy $D$, et al. Plasma natriuretic peptide levels and the risk of cardiovascular events and death. N Engl J Med. 2004;350:655-63.

10. Ledwidge M, Gallagher J, Conlon C, et al. Natriuretic peptide-based screening and collaborative care for heart failure: the STOP-HF randomized trial. JAMA. 2013;310:66-74

11. Viswanathan M, Berkman ND. Development of the RTI item bank on risk of bias and precision of observational studies. J Clin Epidemiol. 2012;65:163-78.

12. Viswanathan M, Berkman ND, Dryden DM, Hartling L. Assessing risk of bias and confounding in observational studies of interventions or exposures: further development of the RTI item bank. Rockville: Agency for Healthcare Research and Quality Methods Research Report; 2013.

13. Higgins JP, Altman DG, Gotzsche PC, et al. The Cochrane Collaboration's tool for assessing risk of bias in randomised trials. BMJ. 2011;343:d5928.

14. Hozo SP, Djulbegovic B, Hozo I. Estimating the mean and variance from the median, range, and the size of a sample. BMC Med Res Methodol. 2005;5:13.

15. Bland M. Estimating mean and standard deviation from the sample size, three quartiles, minimum, and maximum. Int J Stat Med Res. 2015;4:57.

16. Wan X, Wang W, Liu J, Tong T. Estimating the sample mean and standard deviation from the sample size, median, range and/or interquartile range. BMC Med Res Methodol. 2014;14:135

17. Anderson WJ, Lipworth BJ, Rekhraj S, Struthers AD, George J. Left ventricular hypertrophy in COPD without hypoxemia: the elephant in the room? Chest. 2013;143:91-7

18. Gemici G, Erdim R, Celiker A, Tokay S, Ones T, Inanir S, Oktay A. B-type natriuretic peptide levels in patients with COPD and normal right ventricular function. Adv Ther. 2008;25:674-80

19. Sahin Ozdemirel T, Sarin Ulasli S, Yetis B, Karacaglar E, Bayraktar N, Ulubay G. Effects of right ventricular dysfunction on exercise capacity and quality of life and associations with serum NT-proBNP levels in COPD: an observational study. Anadolu Kardiyol Derg. 2014;14:370-7.

20. Wang HY, Xu QF, Xiao Y, Zhang J, Sperry A. Cardiac response and $\mathrm{N}$-terminal-pro-brain natriuretic peptide kinetics during exercise in patients with COPD. Respir Care. 2011;56:796-9.

21. Boschetto P, Campo I, Stendardo M, et al. Plasma sRAGE and N(carboxymethyl) lysine in patients with CHF and/or COPD. Eur J Clin Investig. 2013:43:562-9.

22. Wang R, Cao Z, Li Y, Yu K. Utility of N-terminal pro B-type natriuretic peptide and mean platelet volume in differentiating congestive heart failure from chronic obstructive pulmonary disease. Int J Cardiol. 2013; 170:e28-e9.

23. Beghe B, Verduri A, Bottazzi B, et al. Echocardiography, spirometry, and systemic acute-phase inflammatory proteins in smokers with COPD or CHF: an observational study. PLoS One. 2013;8:e80166.

24. Rutten FH, Cramer MJ, Zuithoff NP, Lammers JW, Verweij W, Grobbee DE, Hoes AW. Comparison of B-type natriuretic peptide assays for identifying heart failure in stable elderly patients with a clinical diagnosis of chronic obstructive pulmonary disease. Eur J Heart Fail. 2007;9:651-9.

25. Gale CP, White JES, Hunter A, et al. Predicting mortality and hospital admission in patients with COPD: significance of NT pro-BNP, clinical and echocardiographic assessment. J Cardiovasc Med. 2011;12:613-8.

26. Macchia A, Rodriguez Moncalvo JJ, Kleinert M, et al. Unrecognised ventricular dysfunction in COPD. Eur Respir J. 2012;39:51-8.

27. Bando M, Ishii Y, Sugiyama Y, Kitamura S. Elevated plasma brain natriuretic peptide levels in chronic respiratory failure with cor pulmonale. Respir Med. 1999:93:507-14.

28. Bozkanat E, Tozkoparan E, Baysan O, Deniz O, Ciftci F, Yokusoglu M. The significance of elevated brain natriuretic peptide levels in chronic obstructive pulmonary disease. J Int Med Res. 2005;33:537-44.

29. Anar C, Yildirim E, Buyuksirin M, Halilcolar H. Diagnostic value of N-terminal pro-B-type natriuretic peptide levels in patients with chronic obstructive pulmonary diseases. Anatolian J Clin Investig. 2012;6:86-91.

30. Watz H, Waschki B, Boehme C, Claussen M, Meyer T, Magnussen H. Extrapulmonary effects of chronic obstructive pulmonary disease on physical activity: a cross-sectional study. Am J Respir Crit Care Med. 2008;177:743-51.

31. Kanat F, Vatansev H, Teke T. Diuretics, plasma brain natriuretic peptide and chronic obstructive pulmonary disease. Neth J Med. 2007;65:296-300.

32. Wang QP, Cao XZ, Wang XD, et al. Utility of NT-proBNP for identifying LV failure in patients with acute exacerbation of chronic bronchitis. PLOS ONE [Electron Resour]. 2013:8:e52553.

33. Stolz D, Breidthardt T, Christ-Crain M, et al. Use of B-type natriuretic peptide in the risk stratification of acute exacerbations of COPD. Chest. 2008;133:1088-94.

34. Marcun R, Sustic A, Brguljan PM, et al. Cardiac biomarkers predict outcome after hospitalisation for an acute exacerbation of chronic obstructive pulmonary disease. Int J Cardiol. 2012;161:156-9.

35. Inoue $Y$, Kawayama T, Iwanaga T, Aizawa H. High plasma brain natriuretic peptide levels in stable COPD without pulmonary hypertension or cor pulmonale. Intern Med. 2009:48:503-12.

36. Nishimura K, Nishimura T, Onishi K, Oga T, Hasegawa Y, Jones PW. Changes in plasma levels of B-type natriuretic peptide with acute exacerbations of chronic obstructive pulmonary disease. Int J COPD. 2014;9:155-62.

37. Lee MH, Chang CL, Davies AR, Davis M, Hancox RJ. Cardiac dysfunction and $\mathrm{N}$-terminal pro-B-type natriuretic peptide in exacerbations of chronic obstructive pulmonary disease. Intern Med J. 2013;43:595-8.

38. Patel ARC, Kowlessar BS, Donaldson GC, et al. Cardiovascular risk, myocardial injury, and exacerbations of chronic obstructive pulmonary disease. Am J Respir Crit Care Med. 2013;188:1091-9.

39. El Mallawany H, Mahmoud MI, Morsi TS, EL-Shiekh RM. Role of N-terminal pro B-type natriuretic peptide in acute exacerbation of chronic obstructive pulmonary disease. Egypt J Chest Dis Tuberc. 2014;63:57-65.

40. Patel ARC, Donaldson GC, Mackay AJ, Wedzicha JA, Hurst JR. The impact of ischemic heart disease on symptoms, health status, and exacerbations in patients with COPD. Chest. 2012;141:851-7.

41. Akpinar EE, Hosgun D, Akpinar S, Atac GK, Doganay B, Gulhan M. Incidence of pulmonary embolism during COPD exacerbation. J Bras Pneumol. 2014:40:38-45.

42. Andersen CU, Mellemkjaer S, Nielsen-Kudsk JE, Sonderskov LD, Laursen BE, Simonsen U, Hilberg O. Echocardiographic screening for pulmonary hypertension in stable COPD out-patients and NT-proBNP as a rule-out test. COPD: J Chron Obstruct Pulmon Dis. 2012;9:505-12.

43. Ouanes I, Jalloul F, Ayed S, et al. N-terminal proB-type natriuretic peptide levels aid the diagnosis of left ventricular dysfunction in patients with severe acute exacerbations of chronic obstructive pulmonary disease and renal dysfunction. Respirology. 2012;17:660-6.

44. Chang CL, Robinson SC, Mills GD, Sullivan GD, Karalus NC, McLachlan JD, Hancox RJ. Biochemical markers of cardiac dysfunction predict mortality in acute exacerbations of COPD. Thorax. 2011;66:764-8.

45. Hoiseth AD, Omland T, Hagve TA, Brekke PH, Soyseth V. NT-proBNP independently predicts long term mortality after acute exacerbation of COPD - a prospective cohort study. Respir Res. 2012;13:97. 
46. Abroug F, Ouanes-Besbes L, Nciri N, et al. Association of left-heart dysfunction with severe exacerbation of chronic obstructive pulmonary disease: diagnostic performance of cardiac biomarkers. Am J Respir Crit Care Med. 2006;174:990-6.

47. Gariani K, Delabays A, Perneger TV, Agoritsas T. Use of brain natriuretic peptide to detect previously unknown left ventricular dysfunction in patients with acute exacerbation of chronic obstructive pulmonary disease. Swiss Med Wkly. 2011;141:w13298.

48. Waschki B, Kirsten A, Holz O, Muller KC, Meyer T, Watz H, Magnussen H. Physical activity is the strongest predictor of all-cause mortality in patients with COPD: a prospective cohort study. Chest. 2011;140:331-42.

49. van Gestel YR, Goei D, Hoeks SE, et al. Predictive value of NT-proBNP in vascular surgery patients with COPD and normal left ventricular systolic function. COPD. 2010;7:70-5.

50. Zeng LH, Hu YX, Liu L, Zhang M, Cui H. Impact of beta2-agonists, betablockers, and their combination on cardiac function in elderly male patients with chronic obstructive pulmonary disease. Clin Interv Aging. 2013:8:1157-65

51. Lee JH, Oh SY, Hwang I, Kim O, Kim HK, Kim EK, Lee JH. The prognostic role of B-type natriuretic peptide in acute exacerbation of chronic obstructive pulmonary disease. [Korean]. Tuberc Respir Dis. 2004:56:600-10.

52. Medina AM, Marteles MS, Saiz EB, Martinez SS, Laiglesia FR, Rodriguez JAN, Perez-Calvo II. Prognostic utility of NT-proBNP in acute exacerbations of chronic pulmonary diseases. Eur. 2011;22:167-71.

53. Yap LB, Mukerjee D, Timms PM, Ashrafian H, Coghlan JG. Natriuretic peptides, respiratory disease, and the right heart. Chest. 2004;126:1330-6.

54. O'Donoghue M, Chen A, Baggish AL, Anwaruddin S, Krauser DG, Tung R, Januzzi $J$. The effects of ejection fraction on N-terminal ProBNP and BNP levels in patients with acute CHF: analysis from the ProBNP investigation of dyspnea in the emergency department (PRIDE) study. J Card Fail. 2005;11:S9-14.

55. Maisel AS, McCord J, Nowak RM, et al. Bedside B-type natriuretic peptide in the emergency diagnosis of heart failure with reduced or preserved ejection fraction. Results from the breathing Not properly multinational study. J Am Coll Cardiol. 2003;41:2010-7.

56. Blyth KG, Groenning BA, Mark PB, et al. NT-proBNP can be used to detect right ventricular systolic dysfunction in pulmonary hypertension. Eur Respir J. 2007;29:737-44.

57. Binder L, Pieske B, Olschewski M, Geibel A, Klostermann B, Reiner C, Konstantinides S. N-terminal pro-brain natriuretic peptide or troponin testing followed by echocardiography for risk stratification of acute pulmonary embolism. Circulation. 2005;112:1573-9.

58. Bazzino O, Fuselli JJ, Botto F, Perez DA, Bahit C, Dadone J. Relative value of $\mathrm{N}$-terminal probrain natriuretic peptide, TIMI risk score, ACC/AHA prognostic classification and other risk markers in patients with non-ST-elevation acute coronary syndromes. Eur Heart J. 2004;25:859-66.

59. Lindahl B, Lindback J, Jernberg $T$, Johnston $N$, Stridsberg $M$, Venge $P$, Wallentin L. Serial analyses of N-terminal pro-B-type natriuretic peptide in patients with non-ST-segment elevation acute coronary syndromes: a fragmin and fast revascularisation during in stability in coronary artery disease (FRISC)-II substudy. J Am Coll Cardiol. 2005;45:533-41.

60. Gerber IL, Stewart RA, Legget ME, et al. Increased plasma natriuretic peptide levels reflect symptom onset in aortic stenosis. Circulation. 2003;107:1884-90.

61. Morello A, Lloyd-Jones DM, Chae CU, et al. Association of atrial fibrillation and amino-terminal pro-brain natriuretic peptide concentrations in dyspneic subjects with and without acute heart failure: results from the ProBNP investigation of dyspnea in the emergency department (PRIDE) study. Am Heart J. 2007:153:90-7.

62. Bayes-Genis A, Lloyd-Jones DM, van Kimmenade RR, et al. Effect of body mass index on diagnostic and prognostic usefulness of aminoterminal pro-brain natriuretic peptide in patients with acute dyspnea. Arch Intern Med. 2007;167:400-7.

63. Fabbri LM, Luppi F, Beghe B, Rabe KF. Complex chronic comorbidities of COPD. Eur Respir J. 2008;31:204-12.

64. Zvezdin B, Milutinov S, Kojicic M, Hadnadjev M, Hromis S, Markovic M, Gajic O. A postmortem analysis of major causes of early death in patients hospitalized with COPD exacerbation. Chest. 2009;136:376-80.

65. Du Q, Sun Y, Ding N, Lu L, Chen Y. Beta-blockers reduced the risk of mortality and exacerbation in patients with COPD: a meta-analysis of observational studies. PLoS One. 2014;9:e113048.

66. Mancini GB, Etminan M, Zhang B, Levesque LE, FitzGerald JM, Brophy $J M$. Reduction of morbidity and mortality by statins, angiotensin- converting enzyme inhibitors, and angiotensin receptor blockers in patients with chronic obstructive pulmonary disease. J Am Coll Cardiol. 2006;47:2554-60.

67. Maisel AS, Krishnaswamy P, Nowak RM, et al. Rapid measurement of B-type natriuretic peptide in the emergency diagnosis of heart failure. $N$ Engl J Med. 2002;347:161-7.

68. Januzzi JL, van Kimmenade R, Lainchbury J, et al. NT-proBNP testing for diagnosis and short-term prognosis in acute destabilized heart failure: an international pooled analysis of 1256 patients: the international collaborative of NT-proBNP study. Eur Heart J. 2006;27:330-7.

69. Roberts E, Ludman AJ, Dworzynski K, et al. The diagnostic accuracy of the natriuretic peptides in heart failure: systematic review and diagnostic metaanalysis in the acute care setting. BMJ. 2015;350:h910.

70. Cleland JG, McMurray JJ, Kjekshus J, et al. Plasma concentration of aminoterminal pro-brain natriuretic peptide in chronic heart failure: prediction of cardiovascular events and interaction with the effects of rosuvastatin: a report from CORONA (controlled rosuvastatin multinational trial in heart failure). J Am Coll Cardiol. 2009:54:1850-9.

71. Fujii T, Otsuka T, Tanaka S, et al. Plasma endothelin-1 level in chronic obstructive pulmonary disease: relationship with natriuretic peptide. Respiration. 1999:66:212-9.

72. Cabanes L, Richaud-Thiriez B, Fulla Y, Heloire F, Vuillemard C, Weber S, Dusser D. Brain natriuretic peptide blood levels in the differential diagnosis of dyspnea. Chest. 2001;120:2047-50.

73. Hemlin M, Ljungman S, Carlson J, Maljukanovic S, Mobini R, Bech-Hanssen $\mathrm{O}$, Skoogh BE. The effects of hypoxia and hypercapnia on renal and heart function, haemodynamics and plasma hormone levels in stable COPD patients. Clin Respir J. 2007;1:80-90

74. Papaioannou Al, Mazioti A, Kiropoulos T, et al. Systemic and airway inflammation and the presence of emphysema in patients with COPD. Respir Med. 2010;104:275-82.

75. Kim MA, Kim DK, Lee $\mathrm{CH}$, Chung HS. The correlation of brain natriuretic peptide (BNP), pulmonary arterial pressure, and St. George respiratory questionnaire (SGRQ) and their changes with a trial of an angiotensin converting enzyme inhibitor. [Korean]. Tuberc Respir Dis. 2010:68:273-9.

76. Murphy CA, Blyth KG, Chaudhuri R, et al. Assessment of the presence of occult myocardial infarction in chronic obstructive pulmonary disease using contrast-enhanced cardiac magnetic resonance imaging. Respiration. 2009;78:263-9.

77. Rubinsztajn R, Nasilowski J, Przybylowski T, Karwat K, Chazan R. Usefulness of NT-proBNP serum level in the diagnosis of dyspnea in COPD patients. Pneumonol Alergol Pol. 2013;81:24-9.

78. Lopez-Sanchez M, Munoz-Esquerre M, Huertas D, et al. High prevalence of left ventricle diastolic dysfunction in severe COPD associated with a Low exercise capacity: a cross-sectional study. PLoS ONE. 2013;8.

79. Agoston-Coldea L, Lupu S, Hicea S, Paradis A, Mocan T. Serum levels of the soluble IL-1 receptor family member ST2 and right ventricular dysfunction. Biomark Med. 2014;8:95-106.

80. Xie X, Wang X, Zhang Y, Han D, Li S, Li M. [Correlation between serum marker variations and pulmonary hypertension secondary to chronic obstructive pulmonary disease]. Nan fang yi ke da xue xue bao = J of South Med Univ. 2013:33:1458-62.

81. Escande W, Duva Pentiah A, Coisne A, et al. Left ventricular myocardial performance index predicts poor outcome during COPD exacerbation. Int J Cardiol. 2014;173:575-8.

82. Martins CS, Rodrigues MJ, Miranda VP, Nunes JP. Prognostic value of cardiac troponin I in patients with COPD acute exacerbation. Neth J Med. 2009;67:341-9.

83. Sanchez-Marteles M, Cecilio-Irazola A, Vano-Sanchis D, Nuviala-Mateo R, Serrano-Martinez S, Perez-Calvo Jl. NT-proBNP in chronic obstructive pulmonary disease patients. [spanish]. An Sist Sanit Navar. 2009;32:235-41.

84. Chi SY, Kim EY, Ban HJ, et al. Plasma N-terminal pro-brain natriuretic peptide: a prognostic marker in patients with chronic obstructive pulmonary disease. Lung. 2012;190:271-6.

85. Hwang YI, Geun MP, Sung YK, et al. Correlation between NT-proBNP and pulmonary arterial pressure in COPD patients. [Korean]. Tuberc Respir Dis. 2007:63:346-52.

86. Mansour AE, Abdelsamad AA, El Arman MM. Prognostic value of plasma brain natriuretic peptide in patients with stable chronic obstructive pulmonary disease. Egyptian J Chest Dis Tuberc. 2012;61:297-300. 
87. Jelic S, Le Jemtel TH. Diagnostic usefulness of B-type natriuretic peptide and functional consequences of muscle alterations in COPD and chronic heart failure. Chest. 2006;130:1220-30.

88. Sanchez-Marteles M, Molina Medina A, Bermejo Saiz E, Ruiz Laiglesia F, Nieto Rodriguez JA, Perez-Calvo Jl. Prognostic value of NT-proBNP in chronic pulmonary disease exacerbation. Med Clin. 2010;135:441-6.

Submit your next manuscript to BioMed Central and we will help you at every step:

- We accept pre-submission inquiries

- Our selector tool helps you to find the most relevant journal

- We provide round the clock customer support

- Convenient online submission

- Thorough peer review

- Inclusion in PubMed and all major indexing services

- Maximum visibility for your research

Submit your manuscript at www.biomedcentral.com/submit 